Cronfa - Swansea University Open Access Repository

This is an author produced version of a paper published in :

Adoption \& Fostering

Cronfa URL for this paper:

http://cronfa.swan.ac.uk/Record/cronfa29941

\title{
Paper:
}

Roberts, L., Maxwell, N., Rees, P., Holland, S. \& Forbes, N. (2016). Improving well-being and outcomes for looked after children in Wales: a context sensitive review of interventions. Adoption \& Fostering, 40(4), 309-324.

http://dx.doi.org/10.1177/0308575916675563

This article is brought to you by Swansea University. Any person downloading material is agreeing to abide by the terms of the repository licence. Authors are personally responsible for adhering to publisher restrictions or conditions. When uploading content they are required to comply with their publisher agreement and the SHERPA RoMEO database to judge whether or not it is copyright safe to add this version of the paper to this repository. http://www.swansea.ac.uk/iss/researchsupport/cronfa-support/ 


\title{
Improving well-being and outcomes for looked after children in Wales: a context sensitive review of interventions
}

\section{Louise Roberts}

Cardiff University

\author{
Nina Maxwell, \\ Cardiff University
}

\section{Paul Rees}

Swansea University

\section{Sally Holland}

Children's Commissioner for Wales

\section{Nicholas Forbes}

University of Bath

\begin{abstract}
Improving outcomes for looked after children and young people has been a long-standing concern in Wales. This article reports the findings of a scoping study which sought to identify interventions aimed at improving outcomes for looked after children that are effective or promising. The study was commissioned by an independent funding body to inform a $£ 5$ million investment programme for Wales. It comprised a rapid review of literature, informed through consultation with an expert advisory panel and groups of young people who had been in care. The article outlines the rapid review method, provides details of shortlisted interventions and describes the interventions subsequently approved for investment. It concludes that although there are many promising interventions which address the factors associated with poor outcomes for looked after children, the evidence base is weak. Nevertheless, It is argued that decision making on interventions should be informed by appraisal of the empirical evidence available, but should also be guided by professional judgment that considers the needs, priorities and preferences of service users, carers, practitioners and policy makers.
\end{abstract}




\section{Keywords}

Looked after children, outcomes, interventions, foster care, policy

Corresponding author:

Louise Roberts, Children's Social Care Research and Development Centre (CASCADE), Cardiff University, School of Social Sciences, Glamorgan Building, King Edward VII Avenue, Cardiff CF10 3WT, UK.

Email: RobertsL18@ cf.ac.uk

\section{Introduction}

Improved outcomes for looked after children have long been an aim of the United Kingdom (UK) and Welsh governments (DCSF, 2009; WAG, 2004; Berridge, 2012). In Wales, a raft of legislation, statutory guidance and policy directives have been designed to address this issue (see, for example, Children Act, 2004 Parts 3-5; Rights and Young Persons, Wales, Measure, 2011; WAG, 2007a,b). Despite some positive change, improved outcomes have generally remained elusive (CSSIW, 2015; Holland, 2015; WAO, 2012), as is the case elsewhere in the UK (see Coman and Devaney, 2011; TSG, 2015). The extent to which obdurately poor outcomes are due to children's pre-care experiences, the care system or other factors remains unclear (Forrester, et al., 2009). What is clear, however, is that in Wales the scale of the challenge is growing as the number of children in care has been rising, currently to 91 children in care per 10,000 of the $0-18$ population, a ratio that is some one third higher than that found in England and Northern Ireland (StatsWales, 2014).

In seeking to understand the underlying factors explaining this difference, it is helpful to reflect on the practice context in Wales. It has been engaged in a process of devolution since the Government of Wales Act (1998) and the transfer of legislative power has created a highly complex practice landscape. Whereas the oversight of education and health have been devolved and led to increasingly idiosyncratic practice compared with the rest of the UK, family and youth 
justice remain the preserve of the UK government. Practitioners in Wales are, therefore, frequently faced with having to attend to directives from two governments that place differing emphasis on, for example, respect for the United Nations Convention on the Rights of the Child (see Rights and Young Persons (Wales) Measure 2011). The recent Social Services and Wellbeing (Wales) Act (2014) has further increased this divergence.

The context of practice in Wales, especially for a mobile population such as looked after children, is further complicated by the relatively large number of municipal authorities, many of which are small. Some argue that this cultivates insular practice which can, in turn, lead to the fragmentation of core services and discontinuity in the provision of care (Williams, 2014). Wales is also a remarkably diverse nation in respect of language, economics and transport networks. Any strategic attempt to improve outcomes for looked after children must, therefore, take into account of a unique and complex mix of legislative, geographical, economic and cultural factors.

This article details the findings of a commissioned scoping study which sought to identify effective or promising interventions specifically for use with looked after children in Wales. The funding was supplied by the Big Lottery Fund (BLF) with the expressed purpose of informing decisions about its $£ 5$ million investment to improve the life chances of looked after children in Wales.

Initially, the 'rapid review' method employed for the study is discussed and details of the shortlisted interventions provided. This is followed by some reflections on the deliberations of the review team in recommending interventions for investment. It will be seen that appraisal of the evidence featured heavily in the process, but that broader issues, such as potential impact and effectiveness with looked after children, were also considered. 
Among the questions asked were:

- Who should be the target of interventions? Some may be suitable for the majority of looked after children while others may be targeted at particular age groups or those with specialist needs.

- Which needs should be targeted? Improved outcomes in certain areas may be particularly desirable as they are likely to have positive 'knock on' effects for other areas of the child's life.

- How should interventions be delivered? Interventions may be delivered via a number of agencies and individuals but the project team was especially interested in the involvement of children.

\section{The needs of looked after children}

An understanding of the needs of looked after children is essential in order to carry out a meaningful appraisal of intervention programmes. But this makes the exercise complex as looked after children are known to experience greater difficulties in a number of areas compared with the general population. These include academic achievement, physical and mental health, behaviour and socialisation. For example, the educational attainment of looked after children in Wales is notably low. In the academic year $2014 / 15$ only $11 \%$ of them obtaining five or more GCSEs (A*C) compared to $58 \%$ of the general population (StatsWales, 2015). Two-thirds arereported as having special educational needs (Meltzer, et al., 2004) and they are more likely to be excluded from school (Axford, 2008). Similar disadvantages have been noted for mental health issues (Sempik, 2010; Meltzer, et al., 2004), risks of self-harm and suicide (Furnivall, 2013) and physical needs that require health service support (Meltzer, et al., 2004; DCSF, 2009a; DCSF, 2009b) due to early pregnancy or substance misuse (Craine, et al., 2014; Panwar and Wilson, 2011). The same situation applies to children's socialisation, relationship formation and maintenance (GuishardPine, McCall and Hamilton, 2007) and subsequent social exclusion (NICE, 2010; Hicks, et al., 2012; Axford, 2008). 
It is important to note, however, that many looked after children perform relatively well in key domains and that there is no single difficulty or constellation of presenting problems that is common to every child (Rees, 2013). Similarly, the profile of individual need is always complex and specific to the individual child and their circumstances.

Although many of these difficulties affect the wider population, the underlying mechanisms that give rise to difficulties may differ for looked after children as many of them have experienced considerable disruption and trauma at a time when formative attachments were developing. When Jones and colleagues (2011, p.621) reviewed 92 studies that mapped intervention outcomes, certain factors stood out as especially significant for such children - namely, placement stability and emotional and behavioural problems which the authors perceived as "key mediators between underlying risk factors and outcomes". The significance of placement stability has also been stressed by Leve and colleagues (2012) while Rees (2013) has emphasised the importance of regular birth family contact for positive performance in key domains. In the light of this evidence, interventions designed to boost placement stability which are sensitive to fundamental underlying issues of attachment, separation, loss, trauma and birth family relationships seemed to be good candidates for investment.

\section{Reviewing the literature}

Having recognised the variety of needs that may be experienced by looked after children, the research team sought answers to the following questions:

- What is the range of interventions that meet the needs and enhance the wellbeing and outcomes of looked after children and which of these are targeted at specific areas, such as education or health and which are or more holistic? 
- Which interventions have the strongest evidence base and are most likely to be applicable to the Welsh context?

- Do interventions which with strong evidence of effectiveness have common elements - If so, what are they?

To get things going, a briefing paper on the study and an invitation to participate as members of an expert advisory group were forwarded to a cross-section of 22 stakeholders organisations involved with looked after children. These organisations were identified by Children in Wales and included representatives from the Welsh Government, statutory services, independent agencies and third sector organisations. Seven young people who have experience of being in the looked after system were also invited and agreed to participate as consultants.

Given the restricted time-scale and the success of this method in health and social work evaluations, a review of the literature was undertaken in the autumn of 2013 using a 'Rapid Review' methodology (Shaw and Holland, 2014). Figure 1 gives an overview of the process, decision points and outcomes. This method streamlines the processes of a full systematic review and takes less time, but, importantly, shares many of its rigorous procedures by setting inclusion and exclusion criteria and a traceable methodology for database searching and analysing findings (Shaw and Holland, 2014; Collins and Fauser, 2004). 
Figure 1. Chart showing rapid review process, decision points and outcomes.

Initial search

Systematic database searches: reference list \& internet trawls \& personal correspondence

Stage 1:

Title screening

\section{Inclusion and exclusion criteria applied}

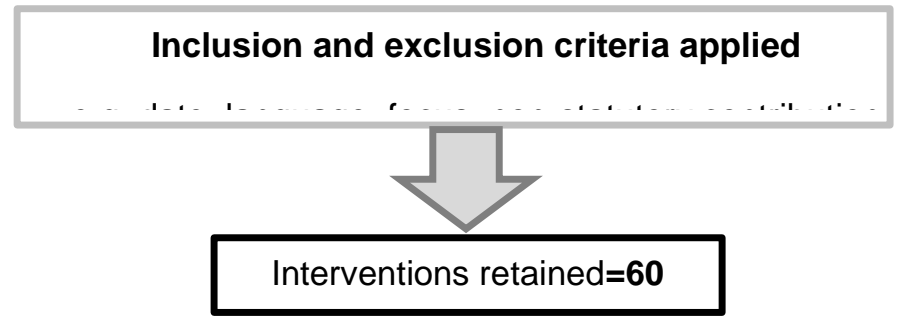

Stage 2:

Abstract/summary screening

Inclusion and exclusion criteria applied

e.g. empirical evaluation, awareness of core issues relating to looked after children, sample

Interventions retained $=32$

Stage 3:

Full paper(s) quality appraisal

Stage 4:

Full paper(s) quality reappraisal \& peer reviewed

\section{Inclusion and exclusion criteria applied}

e.g. theoretical approach, study design, assignment of participant to intervention/control group, use of statistics, effect size, generalisability

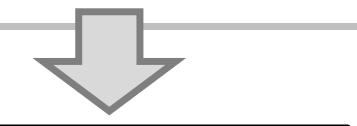

Interventions retained $=18$

Inclusion and exclusion criteria applied e.g. stage 3 criteria with additional focus on potential impact, awareness of core issues, practice relevance, unique nature of intervention and applicability to Welsh context. Consultation with Young People's Group

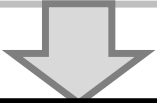

Interventions recommended for consideration $=5$ 
The initial stage of the exercise involved searching for relevant interventions reported in the literature, especially those involving looked after children. In recognition of the broad spectrum of their needs, the search focused on the three domains of education, mental health and health. In all, 1200 separate key word searches were performed across thirteen academic databases and seven relevant websites ${ }^{1}$. The search strategy is further summarised in Table 1.

The search was supplemented by internet trawls, hand searches of journals and reference lists together with suggestions from the expert advisory group, interested organisations and academics. In total, 340 publications were identified. Due to resource constraints, those published before 2000 and/or not in English were filtered out as were interventions with care leavers and those with a very narrow focus, such as repetitive self-harm. As funders had stipulated that interventions must be additional to, or an enhancement of services routinely provided by Welsh local authorities and/or health boards, those patently similar to statutory services were also omitted. In the end, 60 interventions were retained for further examination.

The second stage involved reviewing the abstracts and/or summaries of the 60 interventions. Reviewers considered whether they were supported by robust empirical evidence, showed an awareness of underlying issues such as separation or trauma, and appeared suited to the Welsh context. Thirty-two interventions out of the 60 were retained for further consideration.

\footnotetext{
${ }^{1}$ Social science, social work, psychology, education and medical databases were searched and included Social Care Online, Web of Science, Psychinfo, Medline, ASSIA, Cochrane Library, Campbell Collaboration, National Research Register and NSPCC Inform.
} 
Table 1. Search terms and criteria.

Publication Study design Population and focus

\section{Search terms}

\begin{tabular}{|c|c|c|}
\hline $\begin{array}{l}\text { "Looked after children"; "foster } \\
\text { care"; "kinship care", "residential } \\
\text { care" (NOT older people OR } \\
\text { elderly OR older adults OR adults); } \\
\text { "out of home care" }\end{array}$ & $\begin{array}{ll}\text { English language } & \text { Empirical } \\
\text { Jan. 2000-Oct. 2013. } & \end{array}$ & $\begin{array}{l}\text { Looked after children and young } \\
\text { people }<18 \text { years of age }\end{array}$ \\
\hline AND & & \\
\hline $\begin{array}{c}\text { Education, Mental Health, Health } \\
\text { AND }\end{array}$ & & $\begin{array}{l}\text { Children in foster care (individual or } \\
\text { group interventions). }\end{array}$ \\
\hline $\begin{array}{l}\text { Intervention, support, child } \\
\text { welfare, outcomes }\end{array}$ & & $\begin{array}{l}\text { Education and/or Mental Health } \\
\text { (new/additional/specific interventions) }\end{array}$ \\
\hline
\end{tabular}


The 32 studies were then assigned to individual team members for quality appraisal. The National Institute for Health and Social Care Excellence's Quantitative and Qualitative appraisal checklists (NICE, 2012a b) were used to rate each intervention's methodology as strong, moderate or weak (see Appendix A) and to scrutinise the underlying theory, study design, measures used, target population, use of intervention/control groups, the analysis and findings, especially those that showed a long-term effect on children's functioning. Studies that concentrated on community settings, relationships and problem solving approaches were rated more highly, as were those that directly impacted on the children.

Once this rating exercise was complete, the individual appraisals were shared among the team which reviewed each summary and agreed the studies to be retained. At the end of this stage, 18 interventions were retained (see Appendix B).

In the fourth stage, the 18 interventions were reappraised with heightened attention paid to their potential impact, awareness of underlying issues germane to looked after children, practice relevance and applicability to Wales. There was initial disagreement about the value of four of the 18 interventions but consensus was reached following further discussion. The provisional recommendations for all 18 studies were then discussed by the project team and the advisory panel which drew up a short list of four interventions judged as 'strong' and a fifth as 'weak to moderate'. These can be seen in Table 2. The empirical evidence available on a sixth intervention, Head, Heart and Hands, was rated as weak, but members of the Advisory Panel felt that its emphasis on issues highly relevant to looked after children merited recognition. 
Table 2. Interventions shortlisted for recommendation.

Target group Delivery (schedule/by Description and content Evidence of impact

Intervention

whom)

\begin{tabular}{lllll}
\hline $\begin{array}{l}\text { Fostering } \\
\text { Changes }\end{array}$ & $\begin{array}{l}\text { Carers of 2-12 year } \\
\text { olds, can be adapted } \\
\text { for over 12s. }\end{array}$ & $\begin{array}{l}\text { Weekly, three-hour group } \\
\text { sessions, over twelve weeks. }\end{array}$ & $\begin{array}{l}\text { Adaptation of the Fostering Changes } \\
\text { programme (Pallett, et al. 2005). } \\
\text { Targets behaviour and security. }\end{array}$ & $\begin{array}{l}\text { RCT in UK: intervention grou } \\
(\mathrm{n}=34) \text { control (waitlist) group } \\
(\mathrm{n}=29) .\end{array}$ \\
& $\begin{array}{l}\text { Delivered by: Clinical } \\
\text { Specialists from a Tier } 4 \\
\text { Child and Adolescent } \\
\text { Mental Health clinic }\end{array}$ & $\begin{array}{l}\text { Draws on social learning theory, } \\
\text { attachment theory and cognitive } \\
\text { behavioural techniques. }\end{array}$ & $\begin{array}{l}\text { Improvement on some scales, } \\
\text { including emotional and } \\
\text { behavioural difficulties, } \\
\text { attachment to carers and carer } \\
\text { defined problems. }\end{array}$ \\
& & &
\end{tabular}

\begin{tabular}{|c|c|c|c|}
\hline $\begin{array}{l}\text { Fostering } \\
\text { Healthy } \\
\text { Futures } \\
\text { Programme }\end{array}$ & 9-11 year olds & $\begin{array}{l}\text { Weekly } 1.5 \text { hour skills } \\
\text { groups for thirty weeks. } \\
\text { Delivered by: licensed } \\
\text { clinicians together with and } \\
\text { graduate student trainees) }\end{array}$ & $\begin{array}{l}\text { Developed in Colorado, USA. } \\
\text { Targets mental health and related } \\
\text { issues. Addresses emotion } \\
\text { recognition, problem solving and } \\
\text { anger management. Incorporates } \\
\text { cognitive behavioural activities. } \\
\text { Children mentored by social work } \\
\text { students. }\end{array}$ \\
\hline
\end{tabular}

RCT with longitudinal follow intervention group $(\mathrm{n}=79)$, cor group $(\mathrm{n}=77)$. Statistically significant differences were recorded on mental health $(6$ month follow up), quality of 1 (end of intervention) and placement permanency (1 yea: follow up) suggesting the intervention was effective.

\begin{tabular}{|c|c|c|c|c|}
\hline $\begin{array}{l}\text { Incredible } \\
\text { Years for foster } \\
\text { carers }\end{array}$ & $\begin{array}{l}\text { Carers (primarily for } \\
2-8 \text { year olds but has } \\
\text { been delivered to } \\
\text { carers of young } \\
\text { people up 16) }\end{array}$ & $\begin{array}{l}\text { Group sessions ( } 2 \mathrm{hr}) \\
\text { designed for a maximum of } \\
12 \text { carers over } 12 \text { weeks. } \\
\text { Delivered by } 2 \text { facilitators } \\
\text { Sessions include } \\
\text { discussions, videotape }\end{array}$ & $\begin{array}{l}\text { Emphasises importance of play, use } \\
\text { of incentives, ways to help children } \\
\text { learn, effective praise and ways to } \\
\text { deal with adverse behaviour. }\end{array}$ & $\begin{array}{l}\text { RCT undertaken in Wales: } \\
\text { intervention group }(n=29) \text {, co } \\
\text { group } n=17) \text {. Positive outcom } \\
\text { for intervention group and lov } \\
\text { carer depression levels observ } \\
\text { As a parenting programme ha }\end{array}$ \\
\hline
\end{tabular}


modelling and rehearsal of strategies.

Delivered by: Incredible Years parenting programme mentors. been found to be effective in prevention and in treating con disorders. Endorsed by Welsh English governments. In use world-wide.

\begin{tabular}{ll}
\hline KEEP: & Foster and kinship \\
$\begin{array}{l}\text { Keeping foster } \\
\text { and kinship }\end{array}$ & carers \\
$\begin{array}{l}\text { parents trained } \\
\text { and supported }\end{array}$ & (of age groups 3-6, 5- \\
\hline
\end{tabular}

A 16-20-week programme,
with sessions lasting 1.5 hours each.

Delivered by: Trained facilitator and co-facilitator.
Originated in Oregon, USA. Aims to increase positive parenting skills, improve child outcomes, increase positive placement changes and reduce disruption. Theoretical basis is social learning theory.
Evaluated in USA, RCT $(n=7$ The intervention was positive associated with placement sta and 'positive exits'. Reductior child behaviour problems and increase in positive parenting techniques observed.
Paired Reading Foster carer and child Typical intervention Literacy

Scheme involves: i) training workshops for foster carers/ social workers / and teachers.

ii) carer reading with child for a minimum of 20 minutes, three times a week, for 16 weeks.

Delivered by: i) training, by Paired Reading lead area coordinator and local Educational Psychology Service.

ii) paired reading, by carer(s).
The intervention requires the carer and child to read together and this gradually progresses to the child reading alone. Has potential to foster more positive relationships between school staff and fosters carers as they make contact on a weekly basis.
Small scale pre-post evaluatio with primary aged looked afte children in England, UK. Ave reading ability progressed by year for every month's participation. On-going progr remained uncertain, but findin suggest effective short-term $\mathrm{g}$ Improvements in children's confidence and enthusiasm observed by carers. 


\section{Shortlisted intervention consultation}

Having selected the five most robust interventions, the next decision was where to target the investment. Final recommendations about this were informed by the preferences of the expert advisory panel and young people's group. The former stated a preference for interventions that target more than one aspect of children's well-being, include direct work with young people, have originated in or are transferrable to the UK and have been designed for looked after children and carers. The young people liked interventions that involve direct work with young people, have a broad focus, can be used with those living in residential and foster care, and include some followup element to ensure longer-term sustainability. An additional issue was the extent to which the interventions were compatible with the legislative, political, social, economic and geographical context of Wales, especially the impact on children's overall well-being - a key principle of the Social Services and Wellbeing (Wales) Act 2014.

\section{Results: Investment for Wales}

Following presentation of the findings of the scoping study to the funder, the following selection was approved for investment:

- Fostering Changes (Revised Programme)

- Follow-up Support Group for Carers

- Fostering Healthy Futures (feasibility study)

- Piloting of the Fostering Healthy Futures or an adaption of this programme (determined by the recommendations of the feasibility study) 
This selection will involve a five-year investment ${ }^{2}$ in Fostering Changes (Revised Programme) rolled out on a phased basis across Wales for foster, residential and kinship carers and feasibility studies to explore the process for implementing or adapting the Fostering Healthy Futures programme. The evidence base for both of these programmes is strong. Fostering Changes has been successfully implemented in parts of England since 2009, is age and placement inclusive and focuses on the key priorities for enhancing the well-being of looked after children. Likewise, Fostering Healthy Futures works directly with looked after children. Both initiatives include provision for on-going evaluation.

\section{Discussion}

It is encouraging that this review was able to quickly identify a large number of interventions specifically aimed at improving the outcomes of looked after children and acknowledge the efforts of practice-oriented researchers from a range of disciplines who have highlighted the exceptional needs of such children and sought to fashion effective interventions. But despite this welcome increase in attention, this study has indicated that there is some way to go in establishing a sizeable bank of interventions based on robust evidence of efficacy. Many of the studies deselected reported promising results but had too few participants and/or were focussed on too narrow a subgroup to afford confidence in the generalisability of their findings.

Another common reason for deselection was the lack of evidence of positive impact in key areas of children's functioning. The majority of interventions provided indirect input whichwas mediated through carers, social workers, care workers and teachers. While positive change on

\footnotetext{
${ }^{2}$ The investment is known as the 'XXX' [deleted for peer review process] programme and further details of the programme, the implementation plan and evaluation programme can be accessed via: (XXX) [deleted for peer review process].
} 
indirect outcome measures such as carers' knowledge and satisfaction is pleasing, the inability of many studies to demonstrate any significant effect in key areas of the child's functioning is disappointing.

In recent times the social work profession has been increasingly challenged to demonstrate that its practice is based on sound evidence. Some within the profession have turned, therefore, to evidence based practice (EBP): a scientific model for the appraisal of intervention efficacy which originated in the field of medicine (Straus et al., 2011). An allure of EBP is that it offers a purportedly objective appraisal of evidence which may safeguard against criticism of subjectivity and bias. Integral to EBP is a predetermined hierarchical system of evaluation with meta-analyses of randomised control trials (RCTs) and individual RCTs considered the 'gold standard' and qualitative case studies regarded as inherently weak. Unsurprisingly, EBP is among the most contentious of issues in contemporary social work (Mullen and Streiner, 2004). Critics argue that it is too mechanistic, narrow in focus, impractical and of low ecological validity and restricts clinical judgement or creative interventions, preferring terms such as Evidence-Informed Practice (Nevo and Slonim-Nevo, 2011) or Evidence-Guided Practice (Gitterman and Knight, 2013).

This review has shown that this for and against debate is an oversimplification as in reality there is no substantial body of research evidence available to practitioners (Mullen and Streiner, 2004). Few of the interventions scrutinised in this exercise were highly rated against orthodox EBP criteria, suggesting that empirical research on efficacy in child care is still very much in its infancy, making the current utility of EBP frameworks, at best, restricted. In addition, as the LAC population is immensely heterogeneous and the needs of some children can only be met by interventions tailored to meet a child's specific needs, highly structured interventions have to have 
some flexibility. Users' perceptions and wishes can also be important and have to be incorporated somehow.

All of this made the task of the review team especially difficult; it was charged with recommending intervention(s) for funding which required maintaining the integrity of decision making while employing an eclectic and consultative approach. In one case, an intervention was considered weak scientifically but some members of the expert advisory group clearly liked it and it was retained until the latter stages of the exercise for the purpose of highlighting a novel and promising intervention rather than being nominated as a good investment.

This review also reinforced what practitioners know by experience; there is unlikely to be an intervention that will serve as the panacea for all the challenges faced by the looked after population and it is no surprise, therefore, that a wide range of outcomes were targeted using a myriad of approaches. It is remarkable, however, given the context of practice within Wales and the emphasis on reducing the care population (WAG, 2016; ADSS, Cymru, 2013) that so few studies specifically targeted rehabilitation. It is probable that the authors of many small-scale interventions consider such an objective to be beyond the scope of a 'bolt-on' intervention and the preserve of social services. Paradoxically, however, any intervention that is not closely aligned with the primary objectives of social services, CAMHS and adoption support services may struggle to see meaningful success.

\section{Limitations}

This review was, of necessity, undertaken within a short timescale. The use of rapid review methodology provided a helpful framework, but it is acknowledged that the project team could 
not apply the same degrees of scrutiny to studies as would be typically occur during a full systematic review. In addition, the development of evidence based clearinghouses and repositories in social work have clearly helped to promote EBP and quality ratings of some programmes considered in the review are readily accessible therein. Although these were consulted informally as part of the initial trawl of literature, a structured search strategy was not applied. 


\section{References}

ADSS Cymru (2013) Research on Differences in the Looked After Children Population. CordisBright Consulting: London.

Axford N (2008) Are looked after children socially excluded? Adoption \& Fostering 32(4): 5-18.

BAAF (2014) Statistics: UK. http://www.baaf.org.uk/res/stats.

Berridge D (2012) Educating young people in care: What have we learned. Children and Youth Services Review 34: 1171-1175.

Briskman J, Castle J, Blackeby K, Bengo C, Slack K, Stebbens C, Leaver W and Scott S (2010) Randomised Controlled Trial of the Fostering Changes Programme. https://www.gov.uk/government/uploads/system/uploads/attachment data/file/183398/DFERR237.pdf.

Bywater T, Hutchings J, Linck P, Whitaker C, Daley D, Yeo ST and Edwards RT (2011) Incredible years parent training support for foster carers in Wales: A multi-centre feasibility study. Child Care Health 37(2): 233-243.

Cameron C (2011) Social pedagogy: What questions can we ask about its value and effectiveness? Children Australia 36(4): December 2011.

Cameron C and Petrie P (2011) Social Pedagogy and Foster Care: A scoping study. Thomas Corum Research Unit: Institute of Education: University of London.

Cameron C, Petrie P, Wigfall V, Kleipoedszus S and Jasper A (2011) Final Report of the Social Pedagogy Pilot Programme: Development and implementation. http://eprints.ioe.ac.uk/6767/1/Cameron2011Final\%28Report\%29.pdf. 
Collins JA and Fauser BCJM (2005) Balancing the strengths of systematic and narrative reviews. Human Reproduction Update 11(2): 103-104.

Coman W and Devaney J (2011) Reflecting on outcomes for looked-after children: An ecological perspective. Child Care in Practice 17(1): 37-53.

Craine N, Midgley C, Zou L, Evans H, Whitaker R and Lyons M (2014) Elevated teenage conception risk amongst looked after children: A national audit. Public Health 128: 668-670.

CSSIW (2015) National Inspection of Safeguarding and Care Planning of Looked After Children and Care Leavers. Care and Social Services Inspectorate Wales: Cardiff.

Department for Children Schools and Families (DCSF) (2009a) Promoting the Health of Looked After Children. Research Report DCSF-RR125. http://dera.ioe.ac.uk/11156/1/DCSFRR125.pdf $>$.

Department for Children Schools and Families (DCSF) (2009b) Statutory guidance on promoting the Health and Well-being of Looked After Children. Department for Children Schools and Families, DCSF Publications: Nottingham.

Forrester D, Goodman K, Cocker C, Binnie C and Jensch G (2009). What is the impact of public care on children's welfare? A review of research findings from England and Wales and their policy implications. Journal of Social Policy 38(3): 439-456.

Furnivall J (2013) Understanding Suicide and Self-harm Amongst Children in Care and Care Leavers, CELCIS. http://www.iriss.org.uk/resources/understanding-suicide-and-self-harmamongst-children-care-and-care-leavers.

Gitterman A, and Knight C (2013) Evidence-guided practice: Integrating the science and art of social work. Families in society. The Journal of Contemporary Social Services 94(2): 70-78. 
Guishard-Pine J, McCall S and Hamilton L (2007) Understanding Looked After Children: An introduction to psychology for foster care. London:Jessica Kingsley Publishers.

Hicks L, Simpson D, Mathews I, Koorts H and Cooper K (2012) Communities in Care: A scoping review to establish the relationship of community to the lives of looked after children and young people. http://eprints.lincoln.ac.uk/6066/1/Communities_in_care__A_scoping_review.pdf.

Holland S (2015) Children's Commissioner for Wales: Annual report and accounts. Office of the Children's Commissioner for Wales. Swansea: UK.

Hutchings J (2012) The Incredible Years Programme in Wales. International Journal of Conflict and Violence 6(2): 225-233.

Jones R, Everson-Hock ES, Papaioannou D, Guillaume I, Goyder E, Chilcott J, Cooke J, Payne N, Duernas A, Sheppard LM and Swann C (2011) Factors associated with outcomes for looked-after children and young people: A correlates review of the literature. Child: Care, Health and Development 37(5): 613-622.

Leathers SJ, Spielfogel,JE, McMeel LS and Atkins MS (2011) Use of a parent management training intervention with urban foster parents: A pilot study. Children and Youth Services Review 33(7): 1270-1279.

Leve LD, Harold GT, Chamberlain P, Landsverk JA, Fisher PA and Vostanis P (2012) Practitioner review: Children in foster care - vulnerabilities and evidence-based interventions that promote resilience processes. Journal of Child Psychology and Psychiatry 53(12): 11971211.

Linares LO, Montalto D, Li M, and Oza VS (2006) A promising parenting intervention in foster care. Journal of Consulting \& Clinical Psychology 74(1): 32-41. 
Meltzer H, Lader D, Corbin T, Goodman R and Ford T (2004) The Mental Health of Young People Looked After by Local Authorities in Wales. London: Office for National Statistics.

Mullen EJ, and Streiner DL (2004) The Evidence for and against evidence-based practice. Brief Treatment and Crisis Intervention 4(2): 111-121. http://doi.org/10.1093/brieftreatment/mhh009.

Nevo I, and Slonim-Nevo V (2011) The myth of evidence-based practice: Towards evidenceinformed practice. British Journal of Social Work 41(6): 1176-1197. http://doi.org/10.1093/bjsw/bcq149.

NICE guidance (2010) Looked-After Children and Young People. NICE public health guidance 28. http://www.nice.org.uk/nicemedia/live/13244/51173/51173.pdf.

NICE (2012a) Quality appraisal checklist - quantitative intervention studies. In: Methods for the Development of NICE Public Health Guidance. $3^{\text {rd }}$ Ed. http://publications.nice.org.uk/methods-for-the-development-of-nice-public-healthguidance-third-edition-pmg4/appendix-f-quality-appraisal-checklist-quantitativeintervention-studies.

NICE (2012b) Quality appraisal checklist - qualitative studies. In: Methods for the development of NICE public health guidance $3^{\text {rd }} \mathrm{Ed}$. http://publications.nice.org.uk/methods-for-thedevelopment-of-nice-public-health-guidance-third-edition-pmg4/appendix-h-qualityappraisal-checklist-qualitative-studies.

Nilsen W (2007) Fostering futures: A preventive intervention program for school-age children in foster care. Clinical Child Psychology \& Psychiatry 12(1): 45-63.

Osborne C, Alfano J, and Winn T (2010) Paired reading as a literacy intervention for foster children. Adoption \& Fostering 34(4): 17-26. 
Panwar N, and Wilson O (2011) Substance misuse in looked after children (LAC) of North East Lincolnshire. Archives of Disease in Childhood, 96(Suppl 1): A65-A65.

Price JM, Chamberlain P, Landsverk J, Reid JB, Leve LD and Laurent H (2008) Effects of a foster parent training intervention on placement changes of children in foster care. Child Maltreatment 13(1): 64-75.

Price JM, Chamberlain P, Landsverk J and Reid J (2009) KEEP foster-parent training intervention: Model description and effectiveness. Child \& Family Social Work 14(2): 233242.

Rees P (2013) The mental health, emotional literacy, cognitive ability, literacy attainment and 'resilience' of 'looked after children': A multidimensional, multiple-rater population based study. British Journal of Clinical Psychology 52(2): 183-198.

Rights and Young Persons (Wales) Measure. Welsh Assembly Government. Cardiff: UK.

Sempik J (2010) The Mental Health of Looked After Children Under 5 Years. http://www.nice.org.uk/nicemedia/live/11879/47446/47446.pdf.

Shaw IGR and Holland S (2014) Doing Qualitative Research in Social Work. Sage: London.

StatsWales (2014) A Review of the Comparability of Statistics of Children Looked After by Local Authorities in the Different Countries of the United Kingdom. http://gov.wales/docs/statistics/2014/140523-review-comparability-statistics-childrenlooked-after-local-authorities-en.pdf.

StatsWales (2015) Children aged 16 and over ceasing to be looked after during year ending 31 March by local authority, qualifications and measure. https://statswales.wales.gov.uk/Catalogue/Health-and-Social-Care/SocialServices/Childrens-Services/Children-Looked-After/Educational-Qualifications-of-Care- 


\section{Leavers/childrenaged16andoverceasingtobelookedafterduringyearending31march-by-}

localauthority-qualifications-measure.

Straus SE, Scott Richardson W, Glasziou P and Haynes RB (2011) Evidence-Based Medicine: How to practice and teach it. Edinburgh, London, New York.

Taussig HN, Culhane SE, Garrido E and Knudtson MD (2012) RCT of a mentoring and skills group program: Placement and permanency outcomes for foster youth. Pediatrics 130: 33-39.

Taussig HN and Culhane SE (2010) Impact of a mentoring and skills group program on mental health outcomes for maltreated children in foster care. Archives of Pediatrics and Adolescent Medicine 164: 739-746.

The Scottish Government (TSG) (2015) Getting it Right for Looked After Children and Young People: Early engagement, early permanence and improving the quality of care. The Scottish Government: Edinburgh.

Welsh Assembly Government (WAG) (2004) Children and Young People: Rights to Action. Welsh Assembly Government: Cardiff, UK.

Welsh Assembly Government (WAG) (2007a) Towards a Stable Life and a Brighter Future. Welsh Assembly Government: Cardiff, UK.

Welsh Assembly Government (WAG) (2007b) A Strategy for Social Services in Wales over the Next Decade. Welsh Assembly Government: Cardiff, UK.

Welsh Assembly Government (WAG) (2016) Raising the Ambitions and Educational Attainment of Children who are looked after in Wales: Strategy. Welsh Government: Cardiff.

Welsh Audit Office (WAO) (2012) The Educational Attainment of Looked After Children and Young People. Wales Audit Office: Cardiff. 
Winter K, Connolly P, Bell I and Ferguson J (2011) Evaluation of the Effectiveness of the Letterbox Club in Improving Educational Outcomes among Children Aged 7-11 Years in Foster Care in Northern Ireland. Centre for Effective Education: Queen's University, Belfast.

Williams P (2014) Commission on Public Service Governance and Delivery. Cardiff: Welsh Government. 
Appendix A

Quality appraisal checklist and rating scale.

Description

Rating

Indicates that for that particular aspect of study design, the study has been

$++\quad$ designed or conducted in such a way as to minimise the risk of bias

Indicates that either the answer to the checklist question is not clear from

$+\quad$ the way the study is reported, or that the study may not have addressed all

potential sources of bias for that particular aspect of study design.

Should be reserved for those aspects of the study design in which

significant sources of bias may persist.

Should be reserved for those aspects in which the study under review

Not fails to report how they have (or might have) been considered.

reported

Should be reserved for those study design aspects that are not applicable

Not given the study design under review (for example, allocation

Applicable concealment would not be applicable for case control studies). 


Intervention Key references and information points.

Fostering Changes (revised programme) Dept of Education, Research Report DFE-RR237 Briskman, J., Castle, J., Blac 2010.

Leaver W. and Scott, S. Randomised Controlled Trial of the Fostering Change https://www.gov.uk/government/uploads/system/uploads/attachment_data/file/ Personal communication with K. Blackeby, M. Woolgar and S. Scott from the Taussig, H. N., \& Culhane, S. E. (2010). Impact of a mentoring a health outcomes for maltreated children in foster care. Archives 164, 739-746.

Taussig, H. N., Culhane, S. E., \& Hettleman, D. (2007). Fostering Preventive Intervention for Preadolescent Youth in Out-of-Home www.cebc4cw.org/program/fostering-healthy-futures-fhf/ 
Linares LO, Montalto D, Li M, \& Oza VS. (2006). A promising parenting inte \& Clinical Psychology, 74(1), 32-41.

Bywater, T., Hutchings, J., Linck, P., Whitaker, C., Daley, D., Yeo, S. T., \& E training support for foster carers in Wales: a multi-centre feasibility study. 233-243. http://doi.org/10.1111/j.1365-2214.2010.01155.x

Hutchings, J. (2012). Introducing, researching, and disseminating the Incredib Journal of Conflict and Violence, 6(2), 225.

Personal communication with Hutchings, J.

Price, J. M., Chamberlain, P., Landsverk, J., Reid, J. B., Leve, L. D., \& Laurer intervention on placement changes of children in foster care. Child Maltrea

Price, J. M., Chamberlain, P., Landsverk, J., \& Reid, J. (2009). KEEP foster-p and effectiveness. Child \& Family Social Work, 14(2), 233-242.

Leathers, S. J., Spielfogel, J. E., McMeel, L. S., \& Atkins, M. S. (2011). Use with urban foster parents: A pilot study. Children and Youth Services Revic

$\underline{\text { www.mtfce.org.uk/keep.html } \text { www.baaf.org.uk/ourwork/keep }}$

Personal communication with Collyer, H., South London and Maudsley NHS

Paired Reading Literacy Scheme

Osborne, C., Alfano, J., \& Winn, T. (2010). Paired Reading as a Literacy Inter Fostering, 34(4), 17-26. doi:10.1177/030857591003400403

Winter et al. (2011) 
Cameron, C., Petrie, P., Wigfall, V., Kleipoedszus, S. and Jasper, A. (20 programme: development and imple http://eprints.ioe.ac.uk/6767/1/Cameron2011Final\%28Report\%29.pdf

Personal communication from Tapsfield, R., Fostering Network and Loughbo

ABC: Attachment and Biobehavioral Catch-up Intervention
Bick J., \& Dozier M. (2013). The effectiveness of an attachment-based interve toward foster infants. Infant Mental Health Journal, 95-103.

Dozier, M., Peloso, E., Lewis, E., Laurenceau, J.-P., \& Levine, S. (2008). Effe cortisol production of infants and toddlers in foster care. Development and

Lewis-Morrarty, E., Dozier, M., Bernard, K., Terracciano, S., \& Moore, S. (20 outcomes among foster children: preschool follow-up results of a randomiz 51(2), 17-22.

Our Place

Comfort, R. L. (2007). For the love of learning: Promoting educational achiev Adoption \& Fostering, 31(1), 28-34.

Middle School Success Intervention Kim H.K., \& Leve L.D. (2011). Substance use and delinquency among middle follow-up of a randomized controlled trial. Journal of Consulting and Clini Childwise Herbert, M., \& Wookey, J. (2007). The Child Wise Programme: a course to en management skills of foster carers with challenging children. Adoption \& 
Macdonald, Geraldine, and William Turner. "An experiment in helping foster Journal of Social Work 35.8 (2005): 1265-1282.

Life Books

And

Personal Life History Books

Mental Health and Foster Care training

Cognitively based compassion training CBCT
Holody, R. M., \& Maher, S. (1996). Using lifebooks with children in family f process model. Child Welfare, 75(4), 321 - 336.

Kliman, G. (2006). Methods for maximizing good effects of foster care: evide of foster care and raise IQ. International Journal of Applied Psychoanalytic Minnis, H., Pelosi, A. J., Knapp, M., \& Dunn, J. (2001). Mental health and fos Childhood, 84(4), 302-306.

Reddy, S. D., Negi, L. T., Dodson-Lavelle, B., Ozawa-de Silva, B., Pace, T. W cognitive-based compassion training: a promising prevention strategy for studies, 22(2), 219-230.

Foster carer training programme (un-named)

Hill-Tout, J., Pithouse, A., \& Lowe, K. (2003). Training foster carers in a prev mixed messages from research. Adoption \& Fostering, 27(1), 47-56.

Collaborative mental health care

Wotherspoon, E., O’Neill-Laberge, M., \& Pirie, J. (2008). Meeting the emotio The collaborative mental health care experience. Infant Mental Health Jou http://doi.org/10.1002/imhj.20185

Mental Health (Unnamed)

Callaghan, J., Young, B., Pace, F. and Vostanis, P. (2004) Evaluation of a new Children. Clinical Child Psychology and Psychiatry. 9(1), pp. 130-148. 

and Chamberlain 1994

Leve, L. D., Fisher, P.A. and Chamberlain P.(2009) Multidimensional Treatm

Preventive Intervention to Promote Resiliency Among

Youth in the Child Welfare System. Journal of Personality 77:6. foster care. Children and Youth Services Review, 34(6), 1101-1106. http://

Louise Roberts is a Research Associate, Children's Social Care Research and Development Centre (CASCADE)

Cardiff University, UK.

Nina Maxwell is ..... Cardiff University

Sally Holland is .....Cardiff University

Paul Rees is Associate Professor and the Director of the Centre for Children and Young People's Health and We UK. 
Nicholas Forbes is a Research Assistant at University of Bath, UK. 